\title{
Quality of raw milk supplied to organized milk collection centers of private dairy plant in Nanded district of Maharashtra state
}

\author{
Sonwane Rajkumar Sopanrao
}

\begin{abstract}
The present paper is aimed to analyze the quality of raw milk supplied to organized milk collection centres of private dairy plant in Nanded district of Maharashtra state. The milk samples of Ambachondi, Basmat, Aundha, Balapur, Hingoli and Malegaon was of the best quality and did not contain adulterants.Traces of adulterants like starch, sugar, urea, salt, glucose, formalin and neutralizer adulterants were found in few milk samples.Adulteration practices very in Pimpalgaon location. The tested milk samples indicated the presence of urea, sugar, glucose and formalin.The samples from Aundha and Kurunda location was found adultrant salt.The milk samples of other village locations were also of good quality but location area Pimpalgaon was found to be of substandard in milk quality.Overall conclusion is made of study that the quality of raw milk supplied to organized milk collection centres of private dairy plant in Nanded district of Maharashtra state is appropriate and indicated good nutritional quality of milk.
\end{abstract}

KEY WORDS : Quality of raw milk, Organized milk collection centres, Adulterants

HOW TO CITE THIS PAPER : Sopanrao, Sonwane Rajkumar (2018). Quality of raw milk supplied to organized milk collection centers of private dairy plant in Nanded district of Maharashtra state. Res. J. Animal Hus. \& Dairy Sci., 9(1) : 8-13 : DOI: 10.15740/HAS/RJAHDS/9.1/ 8-13.Copyright@ 2018: Hind Agri-Horticultural Society. 